\title{
Current International Newspapers: Some Collection Management Implications
}

\author{
Stanley P. Hodge and Marilyn Ivins
}

This article discusses current newspaper collection management practices among research libraries; emphasizes the importance of incorporating use patterns into selection decisions; and offers a methodology for surveying the library's international user group. Based on the results of this study, factors to consider when drafting a collection development policy are provided. Interestingly, criteria such as journalistic reputation, geographic representation, and curricular and research support may not accurately reflect users' actual reasons for reading international newspapers.

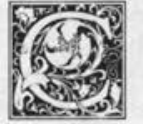

urrent international newspapers $^{1}$ in university libraries are typically acquired on the basis of their journalistic reputations and representative geographic origin to serve as primary source materials for university curricula and research. In "Role of Newspapers as an Information $\mathrm{Re}$ source," Joel Rutstein commented, "There is no broad uniformity of control relating to the selection, processing and handling of current newspapers in academic libraries." 2 And, in "Academic Library Newspaper Collections" Janell Rudolph and Byunn noted, "there seemed to be little, if anything written about acquisition and retention of newspapers by university libraries. ${ }^{\prime 3}$ The published research on library collection management does not indicate how current international newspapers are selected and how frequently they are actually used. A study of selection criteria and of current interna- tional newspaper use would be helpful to those with collection management responsibilities. Thus, the authors determined that obtaining answers to several questions related specifically to international newspapers would be useful to other librarians.

\section{OBJECTIVES AND RESEARCH QUESTIONS}

The purpose of this study is to identify current international newspaper selection patterns in academic research libraries; to determine which selection criteria are considered most important; and to ascertain who typically uses current international newspapers and for what reasons. Questions included

1. How many current international newspapers are typically received by a research library - through paid subscriptions or giftsin English or in a non-English language?

The number of subscriptions placed is

Stanley P. Hodge is Director of Collections Development at Ball State University in Muncie, Indiana 47306. Marilyn Ivins is in the Resource Development Division, Evans Library, at Texas A\&M University, College Station, Texas 77843.

The authors wish to express their appreciation to Peter Hernon for his advice throughout the research process and to Gloriana St. Clair for her comments and suggestions on the final draft. 
interesting beçause the annual cost for an international newspaper may easily exceed $\$ 300$, particularly if it is a daily airmail edition. Although surface mail is far cheaper, a frequent complaint heard from readers of international newspapers is that the latest copy on the shelf is too old to be of interest. Collection development librarians often face the option of selecting a representative title in English or in an indigenous language of another country. Whose language preference should be considered first: the U.S. students who comprise the majority of a university's enrollment or the international students who usually prefer to read in their native language?

2. What are the most and least important criteria considered when selecting a current international newspaper?

Various selection criteria may receive different emphases depending on the collection's purposes and clientele. Even when provided in collection policies, Ross Atkinson notes that these criteria "must still always be interpreted by each selector on the basis of his or her personal experience at the time of each selection decision. ${ }^{\prime \prime 4}$ However, when considered in the abstract, which criteria are considered most important in terms of selecting current international newspapers?

3. What considerations do newspaper policies typically include, and what additional elements might be incorporated when formulating a policy?

Collection development policies serve to guide the selector through making decisions to meet certain stated objectives. A review of research library newspaper policies should theoretically reveal the bases for selection decisions. However, faced with a specific situation, a librarian may use additional selection criteria. When this situation occurs frequently, these additional criteria might be considered for incorporation into newspaper collection policies.

4. How long do research libraries usually retain paper copies of international newspapers, and what are the primary factors in determining their retention period?

A collection manager's job does not end with selection alone. Current newspapers can create special problems, especially when several issues per title are retained. Their size, diverse languages, and tendency to scatter become a nuisance to those responsible for maintaining some semblance of order in the newspaper reading area. Although microfilm holdings decrease these problems for many research titles, the lags in receipt often cause space and access problems.

5. For what reasons are international newspapers actually used and by whom?

Does the use of these newspapers validate the traditional emphasis placed on selection criteria in collection development policies? Again, the literature contains little information on this subject. "The lack of literature treating various approaches to newspaper use suggests that librarians have paid little attention to this major purveyor of information. ${ }^{\prime 5}$

\section{Hypothesis on Newspaper Use}

The authors postulated that the predominant use of current international newspapers is by students primarily for the purpose of obtaining news from their home country. ${ }^{6}$ In order to compare major differences in reading patterns between user groups, it was also postulated (in the form of nondirectional hypotheses) that the same proportion of each type of user group who read international newspapers for five surveyed reasons would be the same proportion as for the other groups combined. (For example, "the proportion of graduate students who read international newspapers for news from home is the same as the proportion of all other user groups who read international newspapers for news from home.") The user groups studied were categorized as faculty, staff, graduate students, undergraduates, and others. The reasons for reading were categorized as class assignment, means of obtaining news from one's home country, current events awareness, recreation, and research.

In order to test these hypotheses, a survey of international newspaper readers in an academic research library was conducted. Such a survey would hopefully produce information to aid that library's collection development officers in the se- 
lection of international newspapers. It would also serve to illustrate how well various selection criteria compare with actual use. Additionally, the methodology and resulting data could well be of interest to other academic librarians coping with the perplexities of international newspaper selection and use.

\section{SURVEY METHODOLOGIES ARL Library Survey}

Two surveys were conducted in order to answer the above questions. First, the ninety-three U.S, university libraries that are members of the Association of $\mathrm{Re}$ search Libraries (ARL) were assigned to one of the four geographic regions: Midwest, Northeast, South, or West. ${ }^{7}$ Second, the libraries in each region were alphabetized according to the name of the institution, and every fourth library for each region was selected for survey purposes.

A questionnaire was developed and pretested by collection development officers at two ARL libraries. Minor modifications were made in the survey instrument. The authors next called the chief collection development officer in each of the twenty selected libraries and asked them to participate in the survey. This procedure enabled the authors to obtain the name of the appropriate librarian to complete the questionnaire. The questionnaires were mailed in May 1985, and by November, responses from eighteen libraries (90 percent) were received.

\section{Newspaper User Survey}

The user survey was conducted at Texas A\&M University's Evans Library in 1985. This library served a student population of 33,859 (spring); 14,491 (first summer session); and 35,675 (fall). The international student population during these terms was $1,584,1,046$, and 1,596 , representing about 100 nationalities. Approximately 58 percent of these international students were graduate students and 42 percent undergraduates. Although the primary focus of the university's curricula is on engineering, science, agriculture, and business, there are sizable enrollments in the colleges of liberal arts and education as well.
The newspaper collection is housed in the Current Periodicals Department of the library; 86 international newspapers representing forty-eight nations are received here. The library receives 25 of these as gifts and purchases 61 through subscriptions; 30 of these newspapers are in English and 56 in other languages.

Evans Library has a newspaper collection policy statement divided into two sections, the first governing microform collections and the second, original paper copy. In the latter, international newspapers are addressed as follows under Scope of the Newspaper Collection:

International newspapers of primary importance are acquired to provide broad coverage on international affairs in areas of the world in which the academic community has a continuing interest; provide news coverage of countries from which the University has a significant number of faculty and/or students; and provide at least one newspaper in each language in which courses at Texas A\&M University are taught. $^{8}$

The survey was conducted through a questionnaire consisting of six multipart questions eliciting twenty items of information. The information sought included the title of the newspaper being read, the reason(s) for reading it, participant status in the university, nationality, and year of arrival in the United States.

Two international students who worked in collection development tested the survey questionnaire with no problems. The first survey was conducted in April 1985. During a one-week period, the authors distributed the questionnaire to readers of current international newspapers every two hours that the library was open for service. While distributing the survey forms, the authors provided a brief introduction and offered to explain or clarify the questionnaire. Two additional surveys were conducted in this manner in June and October of 1985 . $^{9}$

\section{RESULTS AND DISCUSSION Characteristics of Newspaper Collections}

The first question asked about the number of international newspapers acquired; how many are obtained through paid subscriptions or gifts; and the language of 


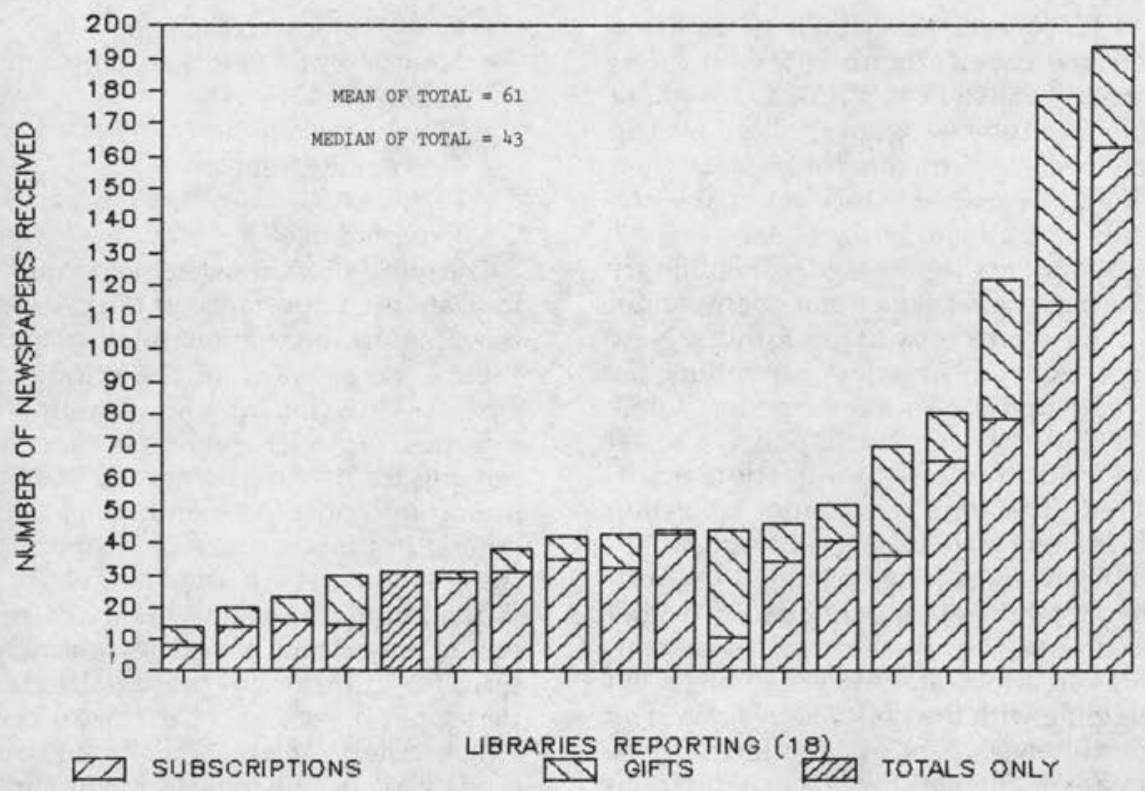

FIGURE 1

Number of International Newspapers Received by Eighteen ARL Libraries

publication. Figure 1 illustrates that the number of international newspapers received through paid subscriptions (and through gifts as well) varies considerably among research libraries. Several factors are likely to affect this phenomenon: materials budgets, number of international students enrolled, type of research and curricular programs emphasized, and librarians' perceived value of newspapers as a service to readers. The "typical" responding library receives 43 (median figure) international newspapers. Seventeen respondents separated paid subscriptions from gifts; the median figures are 34 through subscriptions and 12 through gifts. ${ }^{10}$

It is the authors' opinion that international newspapers may play an important role in undergraduates' liberal education by acquainting them with a broad spectrum of viewpoints and by promoting their respect for other cultures. From this standpoint, and from an assumption that international students are more fluent in English than most U.S. students are likely to be in foreign languages, a case can be made for preferring English-language newspapers when they are available.

The question of language preference was directly addressed in only one of the newspaper collection policies examined. However, a selection predisposition may exist when policy statements emphasize journalistic reputation, or so-called elite newspapers. Respondents were not asked to state their usual practice regarding selection by language, but were requested to indicate how many titles were received in English and non-English languages.

Seventeen libraries responded to the question regarding the receipt of English and non-English titles. The number of English language titles received ranged from 5 to 66 , while non-English titles ranged from 7 to 128. For English-language international newspapers received, the mean average was 22 and the median 18 . The libraries received a mean average of 41 and a median of 25 foreign-language titles. As collections become very large, the foreignlanguage titles predominate.

\section{Policy Statements}

The justifications for a newspaper collection policy statement are similar to 
those for collection policies in general and have been well documented in other sources. ${ }^{11}$ Rutstein has noted, "Without guidelines the newspaper collections can easily become unmanageable, since their bulk and expense lead to formidable demands on staff and budget.",12

Respondents were asked if their library had a newspaper policy statement, and if so, to forward a copy to the authors. Nine of the eighteen libraries responding ( 50 percent) had a newspaper policy, while seven did not; one had a policy in draft stage and one left the question unanswered. The nine newspaper collection policies received vary greatly in length and detail. A few were confined to short, general statements appended to an overall selection policy. In these cases respondents often indicated that they were still struggling with the policy issues raised by current newspapers. As a guide to those who are reviewing their newspaper policies or who are developing one, several factors to consider are outlined in appen$\operatorname{dix} \mathrm{A}$. These are based on the information gained from the two surveys conducted by the authors. ${ }^{13}$

\section{Criteria for Newspaper Selection}

Analysis of the nine newspaper policies received indicated that selection criteria for current international newspapers emphasized

- Quality or journalistic reputation -7

- Curricular or teaching support-7

- Research-7
- Geographic coverage-6

- News from foreign students' home countries-2

- Languages taught-2

- Current awareness-1

- Cost-1

- Expected use-1.

The questionnaire asked respondents to indicate the importance of ten criteria for selecting an international newspaper for their library. Many of the criteria suggested were the same as Rudolph and Byunn used with response categories ranging from "not considered" to "very important" on a five-point scale. The ten criteria in ranked order of importance to the respondents are listed in table 1 .

In addition to seeking librarians' views on the importance of various selection criteria for current international newspapers, one question asked them to ascertain which criteria might actually be considered by a collection development librarian in a hypothetical, but typical, situation:

A student from Andrusia (fictitious country) comes to see you to suggest a newspaper for your library. This student mentions that he has been in the U.S. for only two months and has become concerned about some recent political developments in his country that have resulted in armed insurrections. Your library does not receive a newspaper from Andrusia. What further information would you seek and consider with regard to this student's suggestion that you acquire an Andrusian newspaper?

The responses indicate that when presented with a typical situation, collection

TABLE 1

SELECTION CRITERIA FOR INTERNATIONAL NEWSPAPERS

RANKED IN ORDER OF IMPORTANCE

BY EIGHTEEN COLLECTION DEVELOPMENT LIBRARIANS

\begin{tabular}{|c|c|}
\hline Criteria & Importance \\
\hline 1. Geographical representation & 4.6 \\
\hline 2. Quality or reputation & 4.6 \\
\hline 3. Curriculum support & 4.4 \\
\hline 4. Faculty request & 4.4 \\
\hline 5. Perceived use & 4.4 \\
\hline 6. Cost & 4.1 \\
\hline 7. Student request & 3.1 \\
\hline 8. Index availability & 2.9 \\
\hline 9. Microform availability & 2.9 \\
\hline 10. Recreational interest & 2.0 \\
\hline
\end{tabular}

5 - very important; 4 = moderately important; 3 = equally important/unimportant; 2 = of little importance; $1=$ not considered. 
development librarians are quite perceptive and pragmatic in determining the several possible factors that may have an impact on a selection decision. Some of their answers suggest criteria that should be incorporated in their newspaper collection policies. The categorized answers are listed in table 2 by frequency of mention.

\section{Retention of International Newspapers}

The surveyed librarians were asked how long their libraries generally retain paper copies of international newspapers and which factors were the primary reasons for discarding them. Table 3 illustrates the response and indicates results very similar to those found by Rudolph and Byunn in their study. Nine librarians in the present study qualified the maximum retention period by noting "unless replaced by microfilm."

In stating the primary factor for discarding international newspapers, six librarians indicated space, six indicated use, two indicated space and servicing, and one indicated space and use. Three respondents did not provide a reason. One approach to length of retention is to have no standard period for all newspapers but to consider the criteria of space, use, and servicing on a title-bytitle basis. There may not be a long-term need for many titles acquired by the library. For example, if their use is primarily fulfilling the need for current events awareness, 7 or fewer issues may suffice.

\section{The Use of Current International Newspapers}

The fifth and final collection management question examined was that of current international newspaper use. For what reasons are these newspapers used and by whom? This study has shown that the selection criteria for international newspapers in academic libraries empha-

TABLE 2

RESPONSES TO HYPOTHETICAL QUESTION

Responses to Further Information Sought Frequency

1. The number of university faculty/students from the country or the potential number of readers of a particular newspaper.

2. Cost of the newspaper subscription.

3. The relationship of a newspaper from that nation to the curriculum.

4. The existence of a "recognized" newspaper in that country.

5. Availability of an airmail subscription.

6. The political orientation of a specific newspaper and the reliability of its news.

7. The significance of events in that nation including their importance to U.S. policy.

8. The existence of another paid subscription by the library already covering that region of the world.

9. Budget constraints.

10. Alternative sources of information in the library.

11. Language of the newspaper.

12. The availability of a newspaper from that country in a nearby library.

13. Other single responses.

TABLE 3

RETENTION OF CURRENT NEWSPAPERS

\begin{tabular}{|c|c|c|c|c|}
\hline \multirow[t]{2}{*}{$x=2$} & \multicolumn{2}{|c|}{$\begin{array}{l}\text { Hodge \& Ivins } \\
\text { Study }\end{array}$} & \multicolumn{2}{|c|}{$\begin{array}{l}\text { Rudolf \& Byunn } \\
\text { Study }\end{array}$} \\
\hline & $\begin{array}{c}\text { Number of } \\
\text { Libraries }\end{array}$ & Percent & $\begin{array}{c}\text { Number of } \\
\text { Libraries }\end{array}$ & Percent \\
\hline 2 months or less & 6 & 33.0 & 6 & 26.1 \\
\hline $\begin{array}{l}\text { More than } 2 \text { months } \\
\text { to } 1 \text { year }\end{array}$ & 9 & 50.0 & 11 & 47.8 \\
\hline More than 1 year & 1 & 6.0 & 2 & 8.7 \\
\hline Other & 2 & 11.0 & 1 & 4.3 \\
\hline No answer & 0 & 0 & 3 & 13.0 \\
\hline
\end{tabular}


size geographical representation, journalistic quality or reputation, and support for university curricula and research. But, does the actual use of these newspapers validate the emphasis on these selection criteria?

A 1984 survey questionnaire seeking the reasons for reading newspapers at the University of Notre Dame disclosed the following answers from 229 newspaperreading respondents (see table 4 ). This survey included readers of both foreign and domestic newspapers, the latter being the most heavily used. ${ }^{14}$

\section{Results}

In the Texas A\&M Survey, some 313 questionnaires were completed. Fiftyeight (18.5 percent) of the participants took part in the survey during more than one term. The participants represented 48 nationalities and read 56 different international newspapers. The most frequently read newspapers and the countries of origin most frequently cited by the participants are cited in table 5.

Table 5 indicates that the most fre- quently read newspapers were those representing the nations with the largest number of participants in the survey. This correlation also extends to the total international student body at Texas A\&M during 1985 when students from Taiwan, Korea, and India led all other nationalities in number. Puerto Rican students are not counted in the international student totals because of their United States citizenship. However, evidence of their presence in the university is indicated by the high readership of the Puerto Rican newspaper El Mundo.

The participants represented faculty, staff, graduate and undergraduate students, and a miscellaneous "other" group, composed of visitors, faculty spouses, postdoctoral candidates, former students (an Aggie designation for alumni), and a student from another college in the area. These data clearly indicate that the predominant use of international newspapers is by students, since 261 readers, or 83.4 percent of the readership, were undergraduate ( 28.8 percent) and graduate students ( 54.6 percent). The fac-

TABLE 4

REASONS FOR READING NEWSPAPERS (DOMESTIC AND FOREIGN) UNIVERSITY OF NOTRE DAME SURVEY

\begin{tabular}{lrc}
\hline \hline Reasons & $\begin{array}{c}\text { Total } \\
\text { Responses } \\
\mathrm{n}=229\end{array}$ & $\begin{array}{c}\text { Percentage } \\
\text { Indicating Reason }\end{array}$ \\
\hline To keep up with national and international news & 184 & $80.3 \%$ \\
For news from my hometown & 84 & $36.7 \%$ \\
For news from my home country outside the U.S. & 42 & $18.3 \%$ \\
To learn about the culture/current events of another country & 28 & $15.3 \%$ \\
To improve knowledge of a language & 25 & $12.2 \%$ \\
To locate a piece of information & 24 & $10.5 \%$ \\
To read classified ads & 13 & $5.7 \%$ \\
As a class assignment & 11 & $4.8 \%$ \\
As part of a research project & 9 & $3.9 \%$ \\
\hline
\end{tabular}

TABLE 5

MOST FREQUENTLY READ NEWSPAPERS AND READERS' COUNTRY OF ORIGIN

\begin{tabular}{lrrlc}
\hline \hline $\begin{array}{l}\text { Readers' Country of Origin/ } \\
\text { Number of Readers }\end{array}$ & \multicolumn{1}{c}{ Newspaper } & Times Cited \\
\hline Taiwan & 54 & $18.8 \%$ & China Daily News & 35 \\
& & & Central Daily News (Taiwan) & 16 \\
Korea & 43 & $13.7 \%$ & Korea Times & 44 \\
Puerto Rico & 41 & $13.1 \%$ & El Mundo (Puerto Rico) & 24 \\
India & 22 & $7.0 \%$ & Times of India & 22 \\
\hline
\end{tabular}


ulty accounted for 5.4 percent.

Liberal arts majors were noticeably lacking among student readers. Indeed, further analysis of combined graduate and undergraduate majors showed that $\mathbf{2 6 . 8}$ percent of this group of survey participants were studying engineering, "the most popular field of study among foreign students in 1983/84."15

\section{Reasons for Reading}

For the purposes of this study, the most important data in the survey concerned the reasons for reading current international newspapers. Five choices were listed, and the participants indicated the primary reason(s) for reading. The choices were

1. Class Assignment

2. News from Home

3. Broader Perspective on Current Events

4. Recreational Reading

5. Continuing Research Interest

The respondents were not restricted to one of these choices and often checked several. As figure 2 shows, 87.9 percent of the participants cited "news from home." "Broader perspective on current events" was second with 41.5 percent, followed by "recreational reading" with 33.5 percent.
As in the Notre Dame survey, "research interest" and "class assignment" were of very low priority at 5.4 percent and 1.9 percent respectively. In figure 3 , participants are divided by group according to university status.

These data clearly indicate that "news from home" was the most important reason cited for reading international newspapers. "Getting a broader perspective on current events" ranked second in importance for all the groups, followed closely by "recreational reading." Again, "continuing research interest" and "class assignment" percentages were very low. Faculty and "other" groups did not cite these two reasons at all.

The combined graduate and undergraduate student readers ( 83.4 percent of the total readership) indicated that they primarily read international newspapers for news from their home country ( 88.5 percent of the cases), thereby affirming the authors' basic hypothesis that this was the predominant use. ${ }^{16}$ Furthermore, there was no discernible pattern between the readers' length of residence in the U.S. and the frequency of reading for news from their home countries.

Results for the nondirectional hypotheses concerning proportions of the five

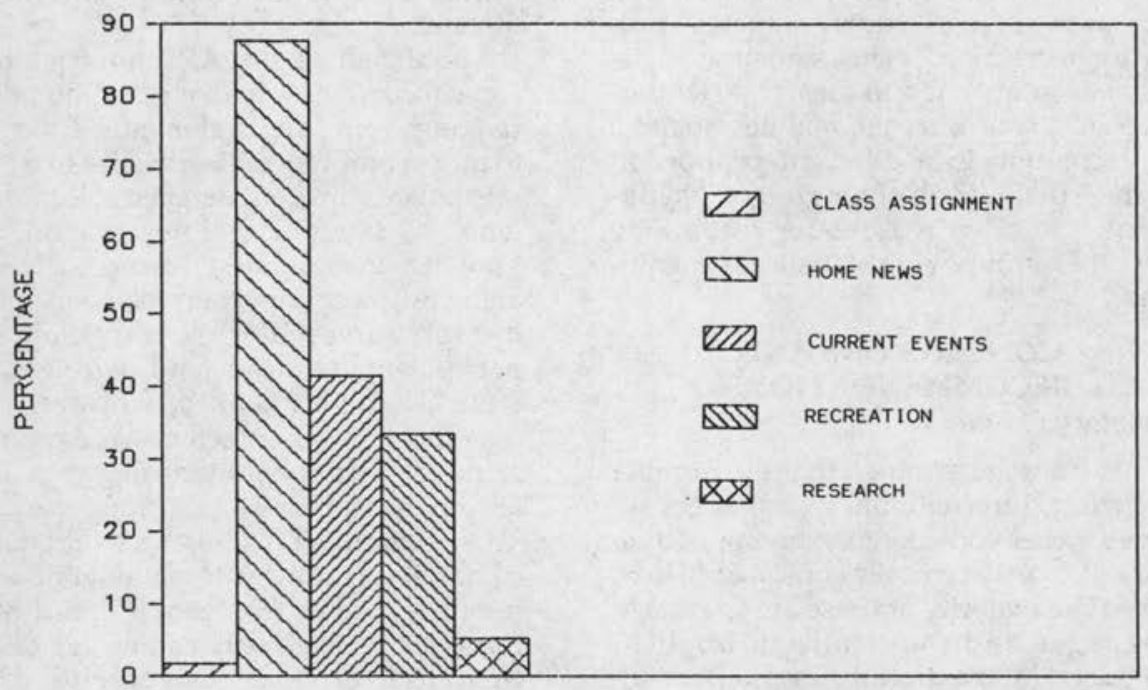

FIGURE 2

Reasons for Reading Newspapers 


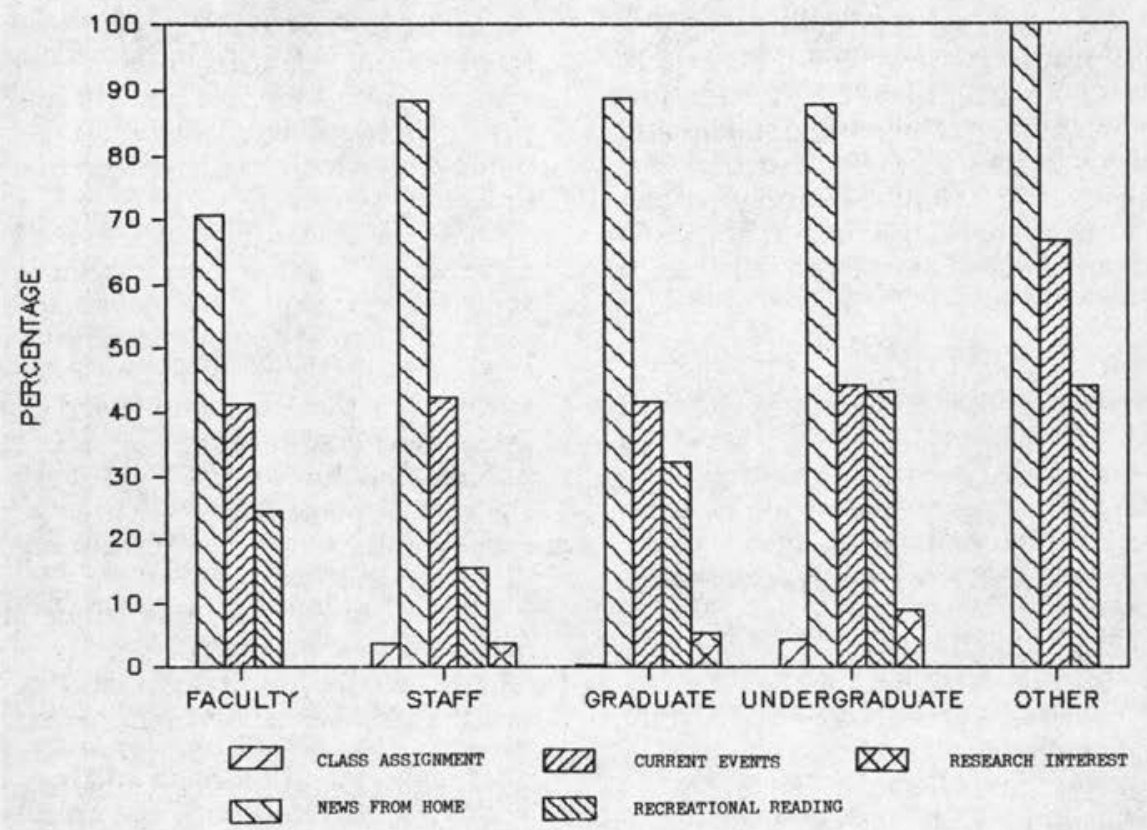

FIGURE 3

Reasons for Reading by University Group

groups of readers and the five reasons for reading international newspapers were also computed using the StatPac corrected chi-square program. The hypothesis of no difference between groups was rejected only in the case of undergraduates reading for recreation. ${ }^{17}$ This statistical rejection was interpreted to mean that undergraduates read international newspapers for recreation in a different proportion (higher) than did all other groups. No differences in other reasons for reading by any other group were statistically significant.

\section{CONCLUSIONS AND RECOMMENDATIONS \\ Summary of Findings}

This study determined that the number of current international newspapers received varies considerably among ARL libraries but may typically consist of 40 to 50 titles. The majority of these are in foreign languages and their ratio to Englishlanguage international newspapers increases as collections grow in size. Gifts account for a significant portion (30-40 percent) of international newspaper titles in most libraries. Paper issues are retained from more than two months to a year by most libraries, space and use being equally cited as reasons for their eventual discard.

About half of the ARL libraries have some form of newspaper selection policy, ranging from brief statements appended to more comprehensive policies to a separate policy with very detailed selection criteria. "Geographical representation" and "quality or reputation" are perceived as being the most important selection criteria by those surveyed, while curriculum support, faculty requests, and perceived use were also highly ranked. However, well over a dozen other factors were reported as possible considerations in a typical selection decision.

User studies at two research libraries indicate that reading international newspapers for "news from home" and other forms of recreational reading far exceed their use for class assignments or research. The use of newspapers by language or country of origin is closely linked 
with the national characteristics of a university's international student body. The authors believe that in newspaper policies more emphasis should be placed on what Atkinson terms the "communal context" of selection. In this context, a primary selector responsibility is to respond to clientele needs determined by systematic and aggressive observation and user studies. ${ }^{18}$

\section{Need for Policy Reviews}

The total number of foreign students in the U.S. for the past thirty years has steadily increased. In 1983-84 international students attended 2,498 academic institutions in the United States. "Their numbers in American higher education will swell from the present 312,000 to over a million in the early 1990's. ${ }^{\prime 20}$ By then, "the presence of foreign students could be one of the most powerful themes in American higher education. "'21

Given the increasing numbers of international students attending U.S. colleges and universities, it seems time for academic librarians in institutions with significant foreign student populations to review their selection policies and practices for acquiring international newspapers. To respond to the needs of this growing enrollment and to hold high costs in check, librarians should solicit gift subscriptions from student associations, embassies, etc. Selectors should also consider subscribing to some of the so-called ethnic newspapers, which are published in the U.S. for foreign-language readers, as a way of eliminating costly airmail rates.
Although these foreign-language newspapers are often slanted by homeland politics, most of them provide reports from the mother country, national news with an ethnic angle, and local cultural calendars. Some examples of the most popular ethnic titles are Philippine News, Korea Times, China Daily News, Nguoi Viet, and Diario las Americas. ${ }^{22}$

While provision of news from one's home country may not appear as lofty an objective as curricular and research support, it may serve no less noble a purpose. Those students from the fictitious Andrusian nation are likely to be struggling with language proficiency, concerned about unstable political conditions in their homeland, adapting to cultural differences, and confronting an alien educational system. A well-selected and responsive international newspaper collection may serve as a vehicle for alleviating separation from their homeland and may provide a crucial link with the culture to which our guests will return. It therefore has the potential to fulfill important social as well as educational roles in academic research libraries.

The results of this research increase our knowledge about current international newspaper collections in academic research libraries. The characteristics of such collections, the primary criteria considered in their selection, and their client use patterns were examined and reported. This information will be useful to collection development librarians in evaluating their own collections and in developing more effective service policies.

\section{REFERENCES AND NOTES}

1. The operational definition of current international newspaper for the purpose of this survey is a publication issued in newsprint and containing general news coverage rather than specific subject matter. It may be published outside the U.S. in English or the national language or within the U.S. in a non-English language.

2. Joel A. Rutstein, "Role of Newspapers as an Information Resource: A Survey of Academic Libraries," Library Scene 7:17-21 (Mar. 1978).

3. Janell Rudolph and Kit Byunn, "Academic Library Newspaper Collections: Developing Policy," College \& Research Libraries 43:80-83 (Jan. 1982).

4. Ross Atkinson, "The Context as Intertext: Toward a Theory of the Selection Process," Library Resources \& Technical Services, 28:109-19 (Apr.-June 1984).

5. Rutstein, p.17. 
6. This postulation was based on observing the use and users of current international newspapers in a research library over a period of several years.

7. U.S. Bureau of the Census, Statistical Abstract of the United States: 1985 (Washington, D.C.: Govt. Print. Off., 1984), fig. 1.

8. Sterling C. Evans Library, Policy Statement \#14B, in "Newspaper Collection Policy" (Jan. 1982), original paper copy.

9. The weeks selected to conduct the reader surveys fell about midsemester in each case. The data from the completed questionnaires were then compiled and analyzed using a StatPac program.

10. Higher mean averages of 61 (total), 45 (subscriptions), and 18 (gifts) are attributed to three very large international newspaper collections.

11. For example: Sheila T. Dowd, "The Formulation of a Collection Development Policy Statement," in Collection Development in Libraries: A Treatise, ed. Robert D. Stueart and George B. Miller, Jr. (Greenwich, Conn.: JAI Pr., 1980), p.67-79; Y. T. Feng, "The Necessity for a Collection Development Policy Statement," Library Resources \& Technical Services 23:39-44 (Winter, 1979).

12. Rutstein, p.20.

13. Three of the more substantial newspaper policies sent were from the libraries of the University of California-Berkeley, Colorado State University, and the University of Texas-Austin. The collection development officers at these institutions have stated a willingness to share their policies with those who request a copy from them.

14. Maureen Gleason, "Report on Newspaper Survey, January 20, 1984." University of Notre Dame Libraries, South Bend, photocopy.

15. Institute of International Education, Open Doors: 1983/84, (New York: IIE, 1985), p.27.

16. Percentages of responses in each category were very consistent in each of the three separate surveys taken over the year. This indicates reliability of findings.

17. Statistical analysis yielded a corrected chi-square value of 4.829 for this reason. A chi-square value of 3.841 or less is required in order for a hypothesis to be accepted at a .05 level of confidence.

18. Atkinson, p.116.

19. Open Doors, p.4.

20. Sally G. Wayman, "The International Student in the Academic Library" Journal of Academic Librarianship 9:336-41 (Jan. 1984).

21. Malcolm G. Scully, "One Million Foreign Students at U.S. Colleges Seen Likely by 1990 ," Chronicle of Higher Education 23:1 (Oct. 21, 1981).

22. James Kelly, "In the Land of Free Speech," Time 126:95-96 (July 8, 1985).

23. Examples of selective lists appear in John C. Merrill, The World's Great Dailies: Profiles of Fifty Newspapers (New York: Hastings, 1980); Martin Walker, Powers of the Press: Twelve of the World's Influential Papers (New York: Pilgrim Pr., 1983); John C. Merrill, ed., Global Journalism: A Survey of the World's Mass Media (New York: Longman, 1983); Linda Ervin, "Building a Collection of Canadian Newspapers," Serials Review, 5:45-48 (Jan.-Mar. 1980). For a good bibliography of sources about African newspapers see John Bruce Howell, "African Newspapers: Current Sources and Retrospective Guides," Serials Review, 10:45-63 (Fall 1984).

\section{APPENDIX A: POTENTIAL ELEMENTS FOR INCLUSION IN A POLICY STATEMENT ON CURRENT INTERNATIONAL NEWSPAPERS}

\section{Reasons for Collecting International Newspapers}

To support continuing curricular requirements

To provide broader coverage of current regional and international events

To provide news from home countries of international students and faculty

To support continuing research interests, i.e., particular geographic regions or area studies programs

\section{Selection Responsibilities}

Those who are assigned to evaluate the collection, to make selection and cancellation decisions, and to determine retention periods 


\section{Potential Selection Criteria}

Quality

Reputation

Language

Political stance

Perceived use (consider international student enrollments by country of origin)

Actual use (based on user studies)

Cost

Availability of airmail, weekly edition subscriptions

Alternative sources of information, e.g., weekly newsmagazines from the country

Selection Tools Used (See reference 23)

\section{Cooperative Arrangements}

Availability of gift subscriptions from student associations, embassies, publishers, or exchange agreements

Consortia

\section{Bibliographic Control and Access}

Types of access provided, e.g., serial listings or indexing

Arrangement on shelves and storage provisions

\section{Newspaper Maintenance}

Those who are responsible for receipt, shelving, and disposal or storage 